\title{
Mineralogical Characterisation of the Sedimentary Phosphate Deposit of Tobène (Western Senegal)
}

Moustapha Diagne ${ }^{1}$, Mamadou Fall ${ }^{1}$, Mouhamadou Bachir Diouf ${ }^{1}$, Ndèye Penda Dione $^{1}$ and El Hadji Mansour $\mathrm{Samb}^{2}$

1. Department of Geology, Faculty of Science and Technology, Cheikh Anta Diop University, Dakar - Sénégal

2. Chemical Industries of Senegal

\begin{abstract}
The Tobène panel is the third of the Taïba phosphate deposit. This mineralogical study contributes to the improved knowledge of the various facies that comprise the phosphate series of Tobène. Based on X-ray diffraction results, the Tobène panel yielded minerals that are primarily divided into four groups: minerals of the original phosphate phase: apatite, fluorapatite; carbonate minerals: calcite and dolomite; clay minerals: palygorskite, smectite, kaolinite and illite; minerals of altered facies: alteration minerals (analcime, millisite, crandallite and wavellite) and ferruginous minerals (goethite and gibbsite). This succession of mineralogical associations reflects a polyphase alteration leading to a vertical and lateral facies sequence. This alteration intensifies the phosphate series upward and laterally from West to East.
\end{abstract}

Key words: Tobène, Taïba, phosphate, mineralogy, Western Senegal.

\section{Introduction}

The West African Atlantic margin, from Morocco to Angola, has been the seat of important phosphate deposits during the Cretaceous and Eocene ages, according to Lucas and Prevot [1]. In the tropical zone, these deposits were subsequently altered, leading to the formation of alumino-calcic phosphate. The phosphate deposit of Taïba, situated between Mboro and Tivaouane approximately $80 \mathrm{~km}$ in the north-east of Dakar (Fig. 1), was discovered in 1948 by "Bureau Minier de la France d'Outre Mer" (BUMIFOM). In subsequent years, mineralogical studies have been undertaken on the panels of Ndomor Diop, Keur Mor Fall $[1,2]$ and, recently, on the Tobène panel [3-7]. Those different studies helped to determine the mineralogical composition of the phosphate series.

The aim of this study on the Tobène panel is therefore to specify the mineralogical composition of the phosphate series in order to elucidate the transformation mechanisms of the calcium phosphate

Corresponding author: Moustapha Diagne, Ph.D., doctor, research field: sedimentology. (having apatite as main mineral) into alumino-calcic phosphate.

\section{Geological Context of the Tobène Deposit}

The Tobène phosphate deposit (Taïba) is located in the western section of the Senegal-Mauritania-Guinea basin. This large basin (approximately 340,000 km²) is located on the West African passive margin.

The basin extends from Nouadhibou (Mauritania) in the North, where it leans over the Precambrian of the Reguibat ridge, to Guinea-Bissau in the South, where it rests on the Silurian-Devonian of the Bowe basin. In the East, the basin leans on the folded and metamorphosed sediments of Infracambrian to lower Paleozoic age of the Mauritanides, according to Dillon and Sougy [8]. In the West, the basin opens on the Atlantic Ocean [9] (Fig. 2).

Regarding the phosphate series, the proposed synthetic $\log$ has been updated several times by Refs. [1, 3, 4, 10-16]. The last update performed by Ref. [5] (Fig. 3) has been revised by Ref. [9] in the context of the revision of geological maps of Senegal 1/500,000. 


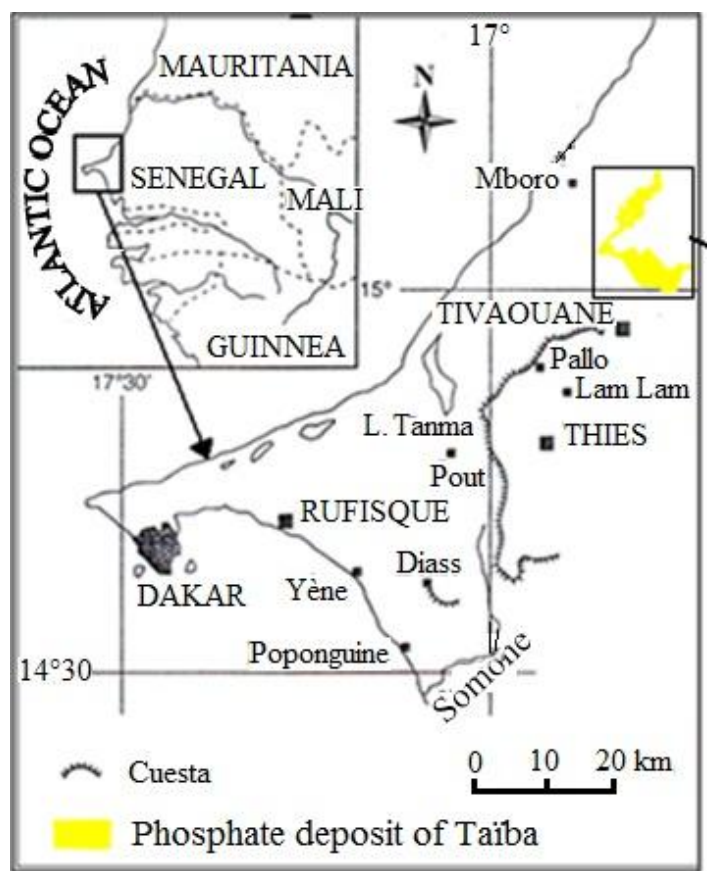

N 1 (Ndomor Diop 1) exploited from 1960 to 1974.

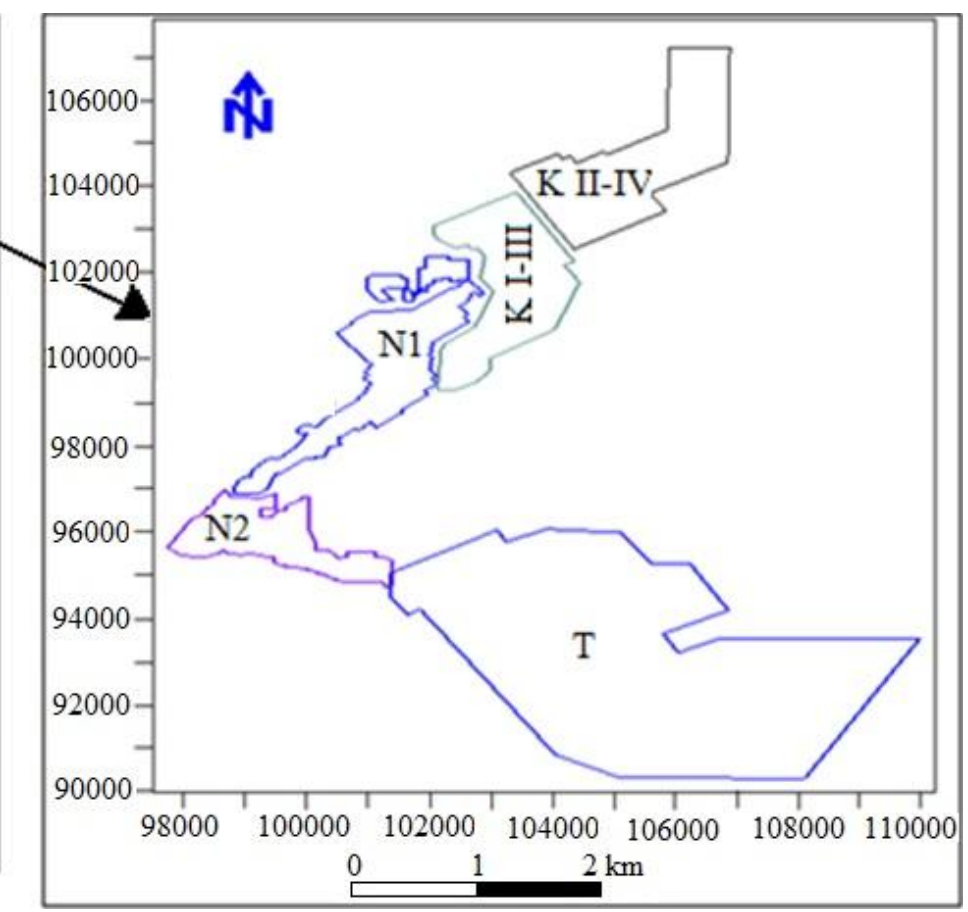

N2 (Ndomor Diop 2) exploited from 1974 to 1980.

K I-III (Keur Mor Fall I-III) exploited from 1981 to 1990.

K II-IV (Keur Mor Fall II-IV) exploited from 1991 to 2003.

$\mathrm{T}$ : panel of Tobène under working.

Fig. 1 Location map of the Taïba deposit and its various panels.

The fossils described in the lithological units of the phosphate series and allowing their dating were determined according to the following methodology. Thus, the studied samples were disintegrated in a solution of hydrogen peroxide at 110 volumes to eliminate organic matter, washed with water, and then sifted with $1 \mathrm{~mm}, 125 \mu \mathrm{m}$ and $63 \mu \mathrm{m}$ sieves. The arenic fraction was then isolated, dried in a drying oven and sorted under a binocular lump to extract the fossils before the determination of the species [17-20].

From bottom to top, this log shows:

- foliated attapulgite clay, of yellow to ochre colour, equivalent of "Marl of Lam-Lam"; in places, sediments are clayey limestones. This unit is attached to the Formation of Lam Lam [9]. According to Flicoteaux [9], this formation delivered a rich association of planktonic foraminifera: Truncorotaloides rohri, T. topilensis, Globigerapsis sp., G. index, Globorotalia collactea, G. bolivariana,
G. pentacamerata and Hantkenina sp, typical of the biozone P11 (middle Lutetian);

Phosphate formation with two members:

- a lower member consisted of heterogeneous calcium phosphate of colour from beige to brown, associated with flint often in benches and with inclusions of different types; this member is sometimes brecciated at its base with secondary accumulations of apatite, iron oxide, aluminium and silica;

- an upper member consisted of homogeneous calcium phosphate, often soft or even pulverulent, less silicified, with various colours and clay intercalations.

This formation of the phosphate group, comprising two members, is attached by Flicoteaux [9] to the Globorotalia lehneri biozone (P12, can also be the top of P11) characteristic of the late Lutetian.

- variegated clay, sometimes phosphatic, constituting the roof clay;

- second formation with alteration alumina 
phosphate with platy flint rich in Daucina, alternating with clay and phosphate sand; this set forms the silico-ferralitic unit often phosphated at its base.
However, the works of Ref. [9] assembled variegated clays and silico-ferralitic unit in the upper formation which is located, according to Tessier et al. [9],

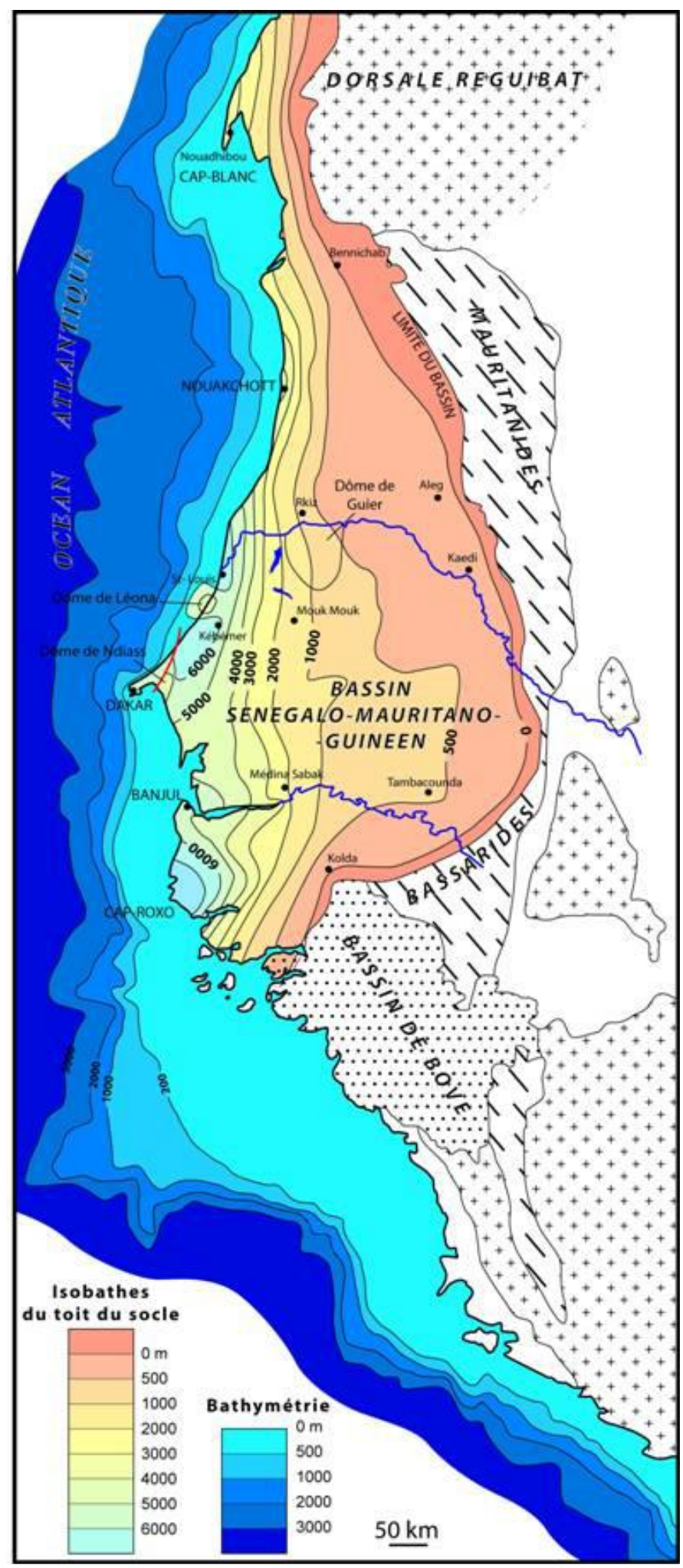

Fig. 2 Regional context of the Senegal-Mauritania-Guinea sedimentary basin [9]. 


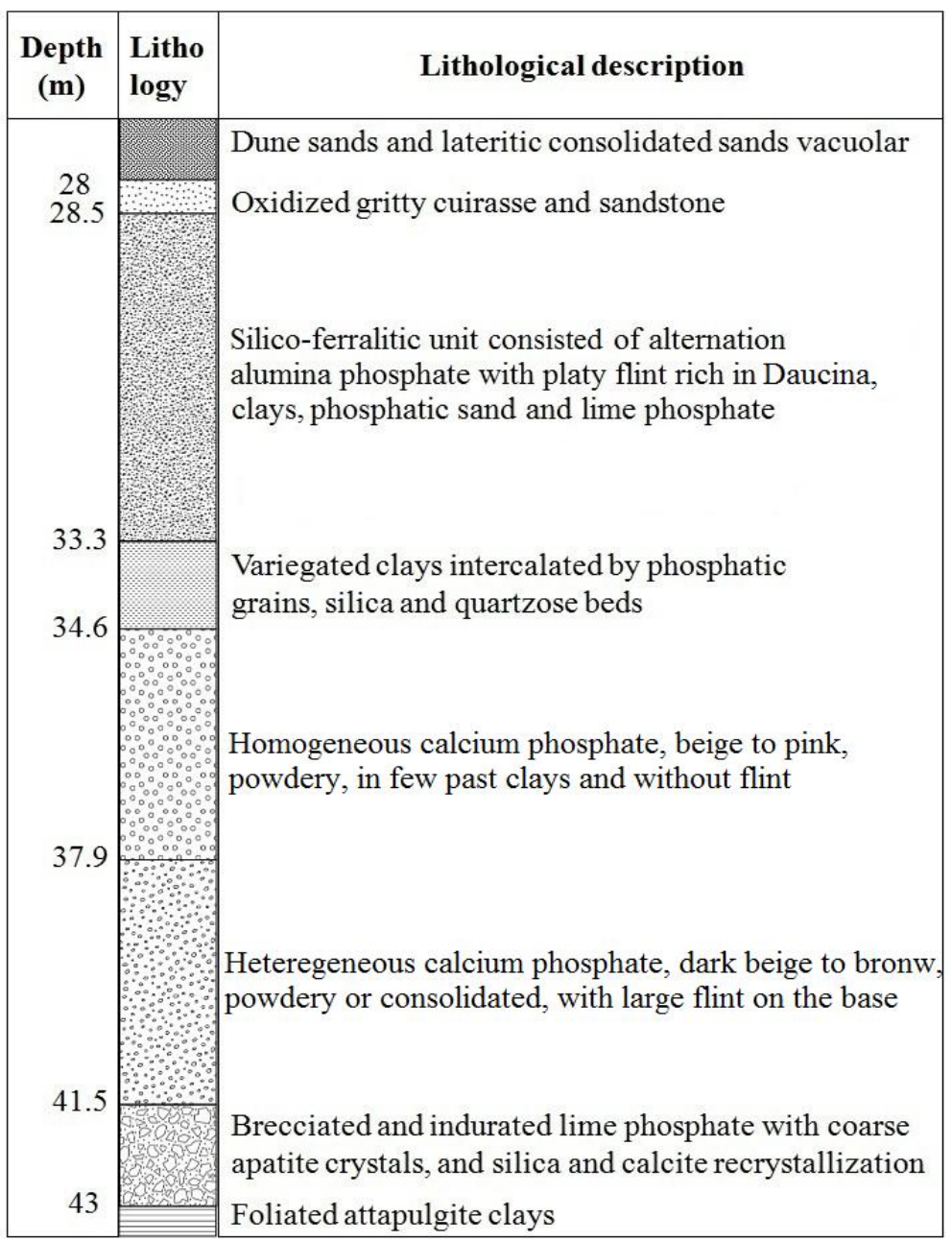

Fig. 3 Synthetic lithological profile of the Tobène deposit [5].

in the biozone of Porticulasphaera mexicana and Truncorotaloides Rohri (P14, can be also P13) characteristic of Bartonien.

Finally, Refs. [6, 7] demonstrated that the phosphate series of Tobène vary laterally in its facies and its thickness and are also reduced in places to four units with a lack of heterogeneous phosphate.

\section{Materials and Analysis Method}

Twenty five boreholes, distributed over all Tobène sectors, were selected. From these boreholes, 87 samples were obtained on different lithological phosphate units.

Mineralogical analysis of the phosphate samples, accomplished on disoriented powder, is performed at the laboratory of the "Centre de Formation et de Recherche sur les Environnements Méditerranéens de
l'Université de Perpignan (CEFREM)" using a cobalt anticathode diffractometer.

X-ray diffraction is one of the methods recommended in the case of phosphate minerals, according to Fisher [1], mainly due to the very small size of the crystals, McConnel [1].

The identification of minerals of each diffractogram has allowed to determine the qualitative mineralogical composition of each sample.

\section{Results and Discussion}

\subsection{Boreholes Mineralogical Description}

\subsubsection{UILJ Borehole (Figs. 4 and 5)}

The mineralogical analysis of heterogeneous phosphate reveals a composition that is dominated by fluorapatite logically associated with apatite but also 


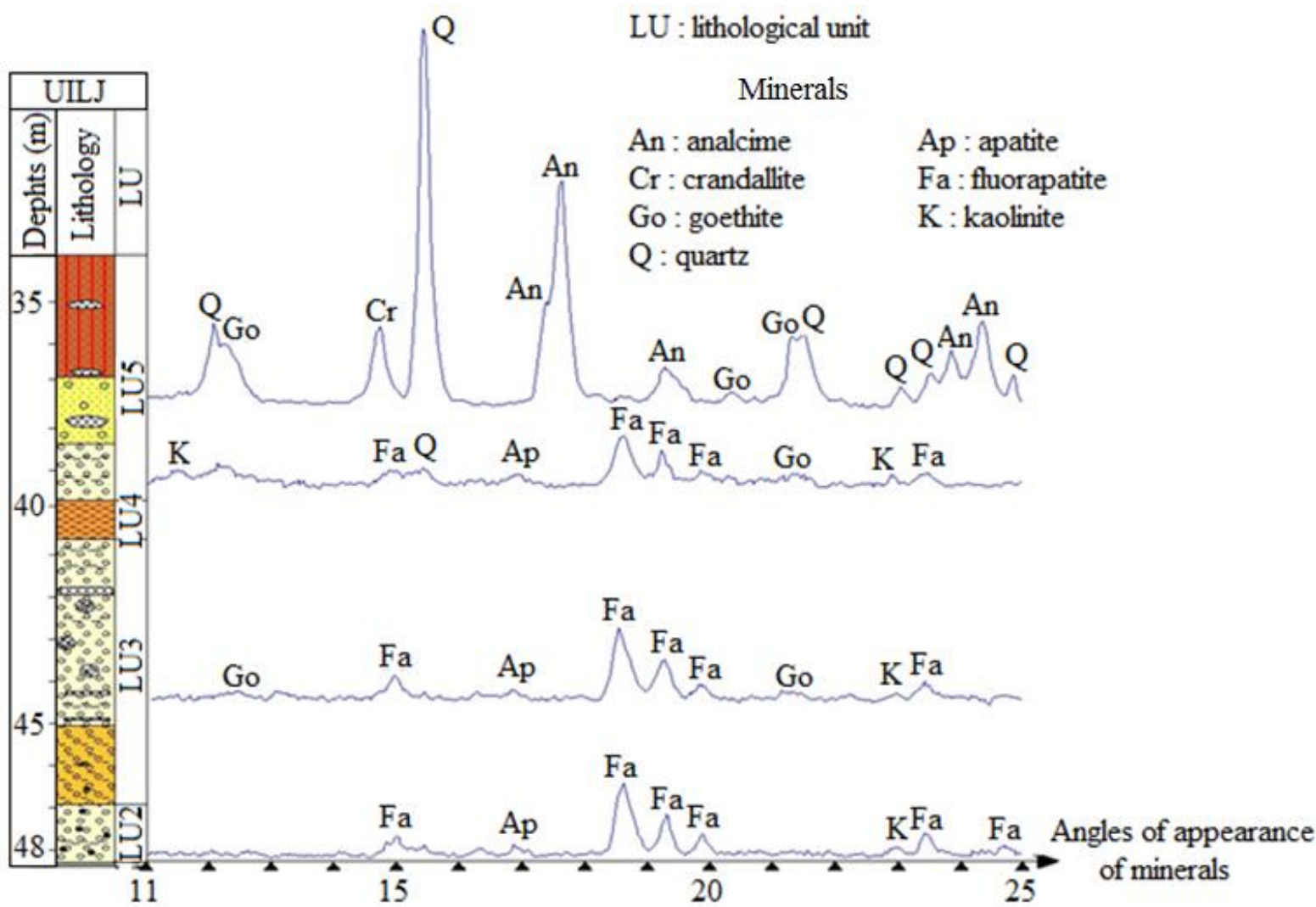

Fig. 4 Lithology of the UILJ borehole and the diffractograms of the analysed phosphate samples.

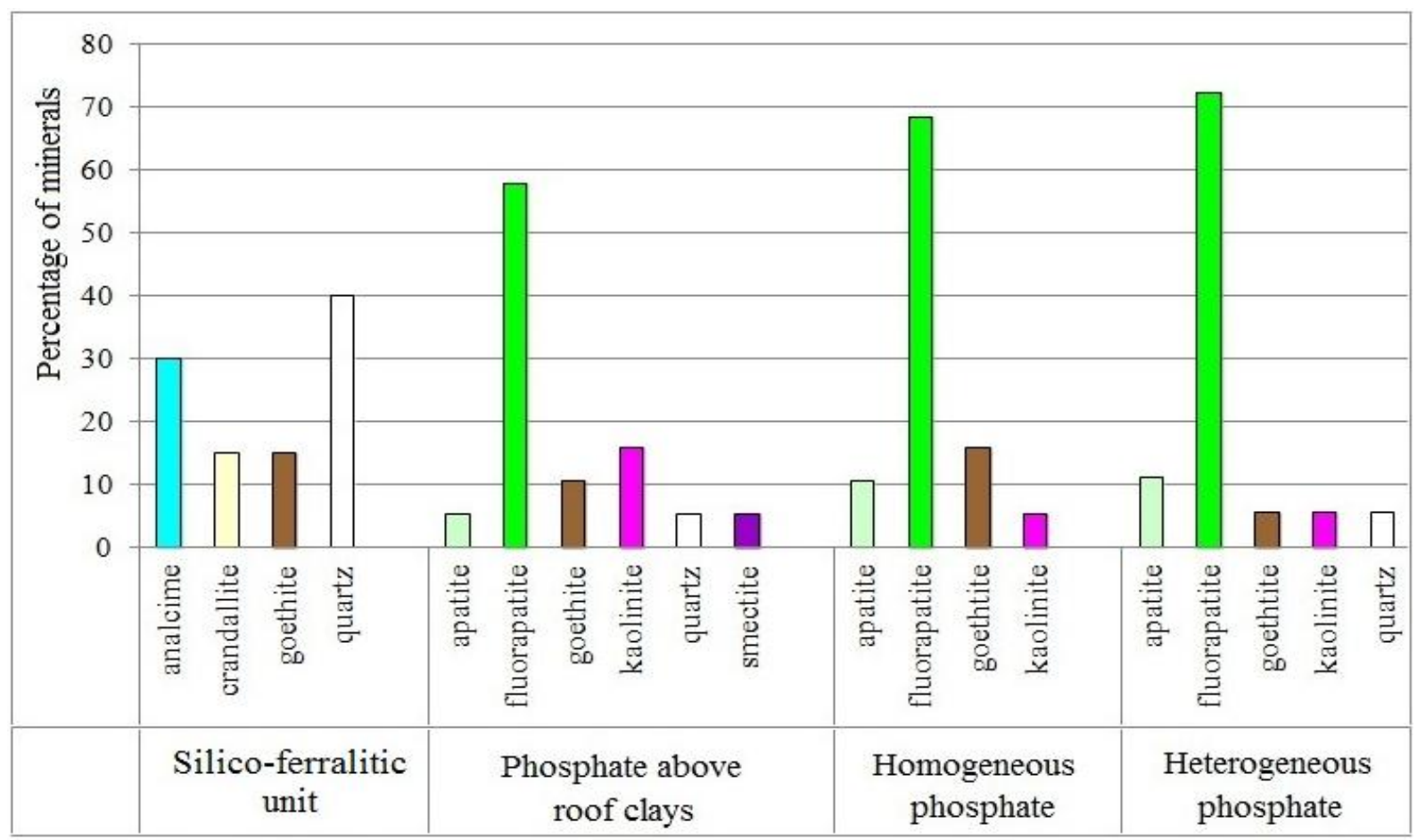

Fig. 5 Lithological units of the UILJ borehole and their mineralogical association. 
with goethite, kaolinite and quartz. In homogeneous phosphate, this association is slightly poorer, with the disappearance of quartz.

The phosphate above the roof clays is characterised by a slight decrease of fluorapatite and apatite, while the amount of kaolinite increases. Note the occurrence of smectite. These observations indicate a clayey presence more marked in this phosphate than in heterogeneous and homogeneous phosphate.

In the silico-ferralitic unit, apatite and fluorapatite disappear completely, being replaced by altered minerals (analcime and crandallite). This mineralogical evolution is accompanied by an intensification of the silicification and ferruginisation, as evidenced by the increasing amounts of quartz and goethite.

Ultimately, the decrease of the apatite and fluorapatite amounts from the bottom to the top of this borehole and their disappearance due to the emergence of altered minerals (analcime and crandallite) at the silico-ferralitic unit, suggest that apatite remains the support of the altered minerals. This intensification in the altered state is confirmed by an increase in the amounts of kaolinite and goethite.

\subsubsection{EIQQ Borehole (Figs. 6 and 7)}

This borehole has a relatively diversified mineralogical composition, especially on the top and at the bottom.

Thus, heterogeneous phosphate is characterised by a mineralogical composition formed by fluorapatite, apatite, analcime, goethite, quartz, palygorskite, millisite, wavellite and illite. The presence of palygorskite would indicate a contamination of the lithological unit of the wall, which consists of attapulgite. The illite would be newly formed, and the importance of quartz would be related to the precipitation of dissolved silica in the overlying units.

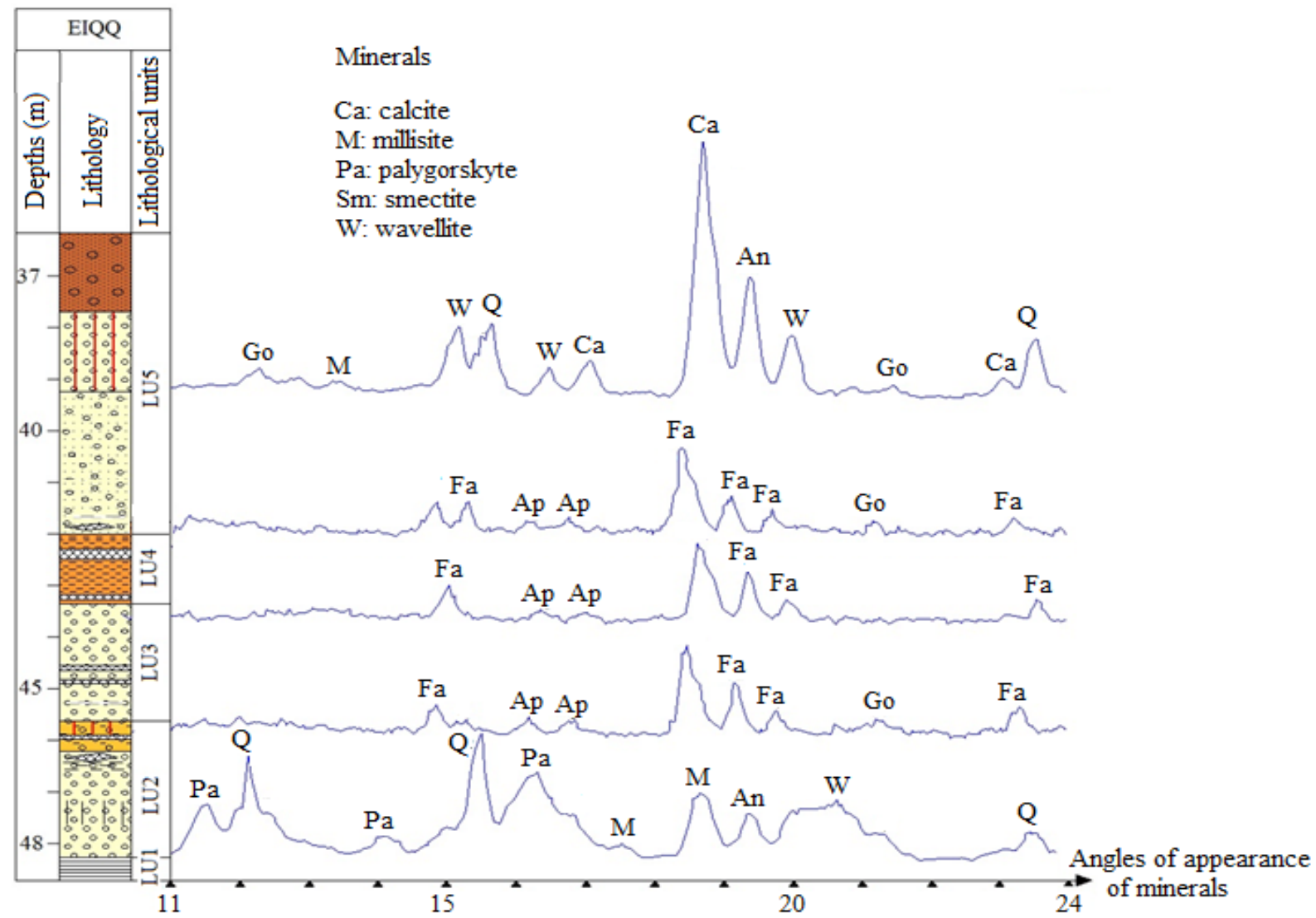

Fig. 6 Lithology of the EIQQ borehole and the diffractograms of the analysed phosphate samples. 


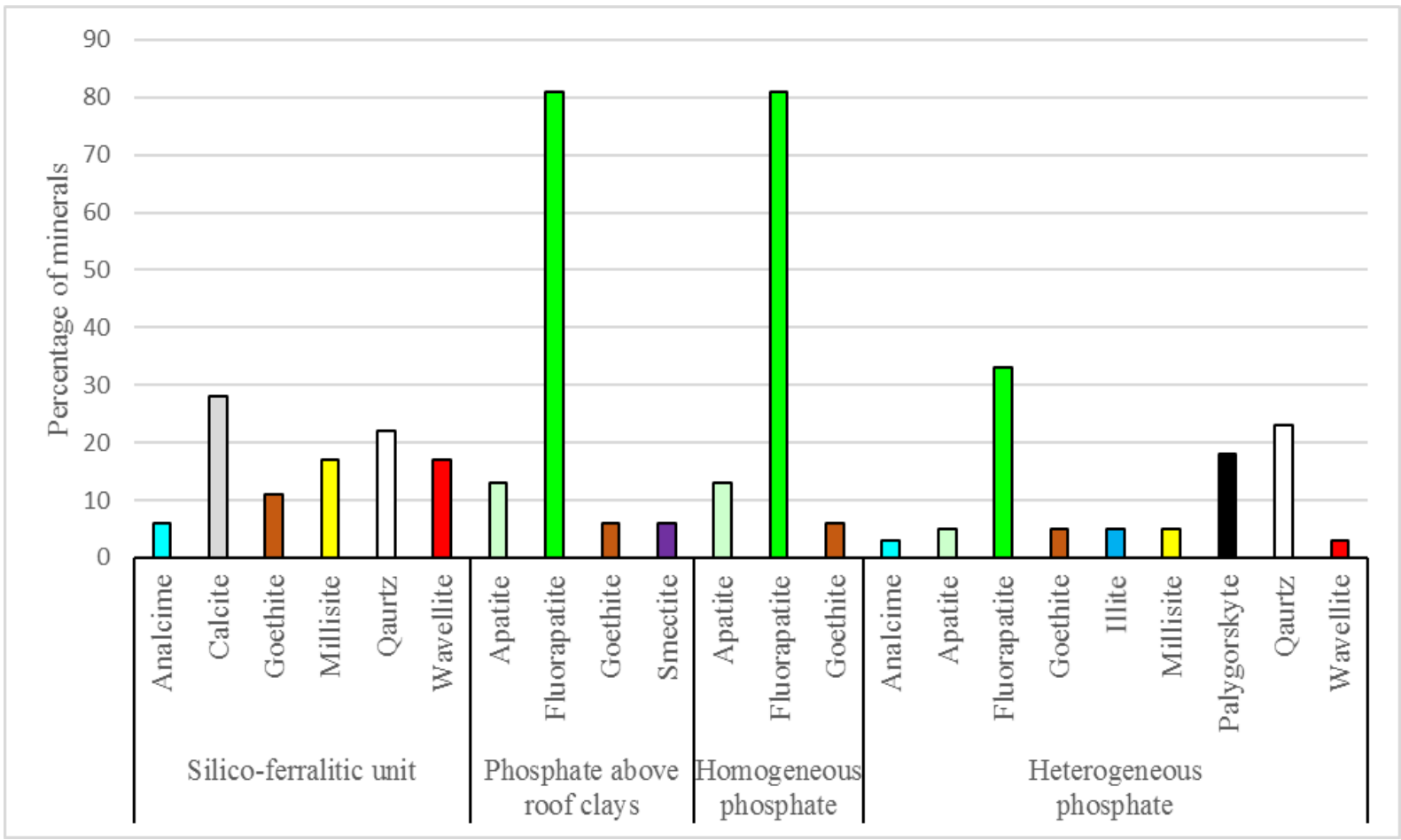

Fig. 7 Lithological units of EIQQ borehole and their mineralogical association.

In homogeneous phosphate, the mineralogical composition is reduced notably to fluorapatite associated with apatite and goethite.

Finally, the silico-ferralitic unit exhibits a strong presence of the alteration minerals (analcime, millisite, wavellite) accompanied by an increase of goethite amount. As in the UILJ borehole, this borehole also exhibits a disappearance of apatite minerals in the silico-ferralitic unit. These facts indicate an intense alteration in the uppermost part of the deposit.

\subsubsection{AYND Borehole (Figs. 8 and 9)}

Except for the quartz in the homogeneous phosphate, the phosphate formation exhibits a simple mineralogical composition: apatite, goethite and fluorapatite with a predominance of the latter.

In the silico-ferralitic unit, phosphated minerals (apatite and fluorapatite) are replaced by alumino-calcic minerals (millisite, crandallite), which are associated with analcime, goethite and quartz. These facts also reflect a more intense alteration of the top of the phosphate series.

\subsubsection{UIGQ Borehole (Figs. 10 and 11)}

The preponderance of clay minerals (kaolinite and smectite) in the roof of the phosphate formation logically proves its clayey nature. As for the mineralogical association quartz, goethite, gibbsite and crandallite, it indicates alteration of the level of clay.

In heterogeneous phosphate, the dominant mineral is fluorapatite, which is combined with apatite, smectite, quartz and goethite. Smectite highlights the clayey presence in this part of the ore, while the quartz reflects a silicification marked by flint benches. Goethite, which content increases towards the top, marks an intensified ferruginisation.

\subsection{Mineralogical Correlations}

To specify the relationship between minerals and facies, we determined the correlation coefficients between the minerals identified. To perform the correlation, we used the SPSS software specialised in the treatment of statistical data.

In the East-central sector of Tobène, the correlation coefficients (Table 1) helped to determine mineralogical associations.

The first group of minerals consists of apatite and 


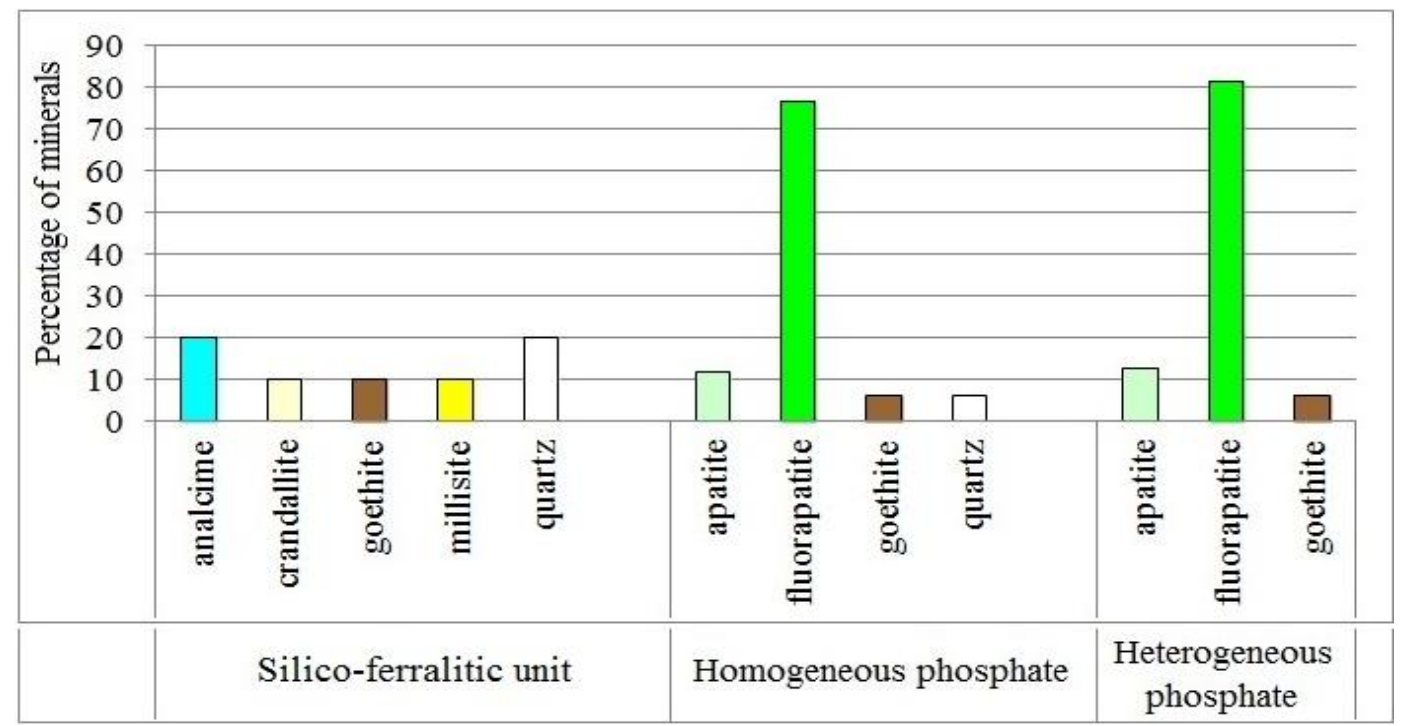

Fig. 8 Lithological units of the AYND borehole and their mineralogical association.

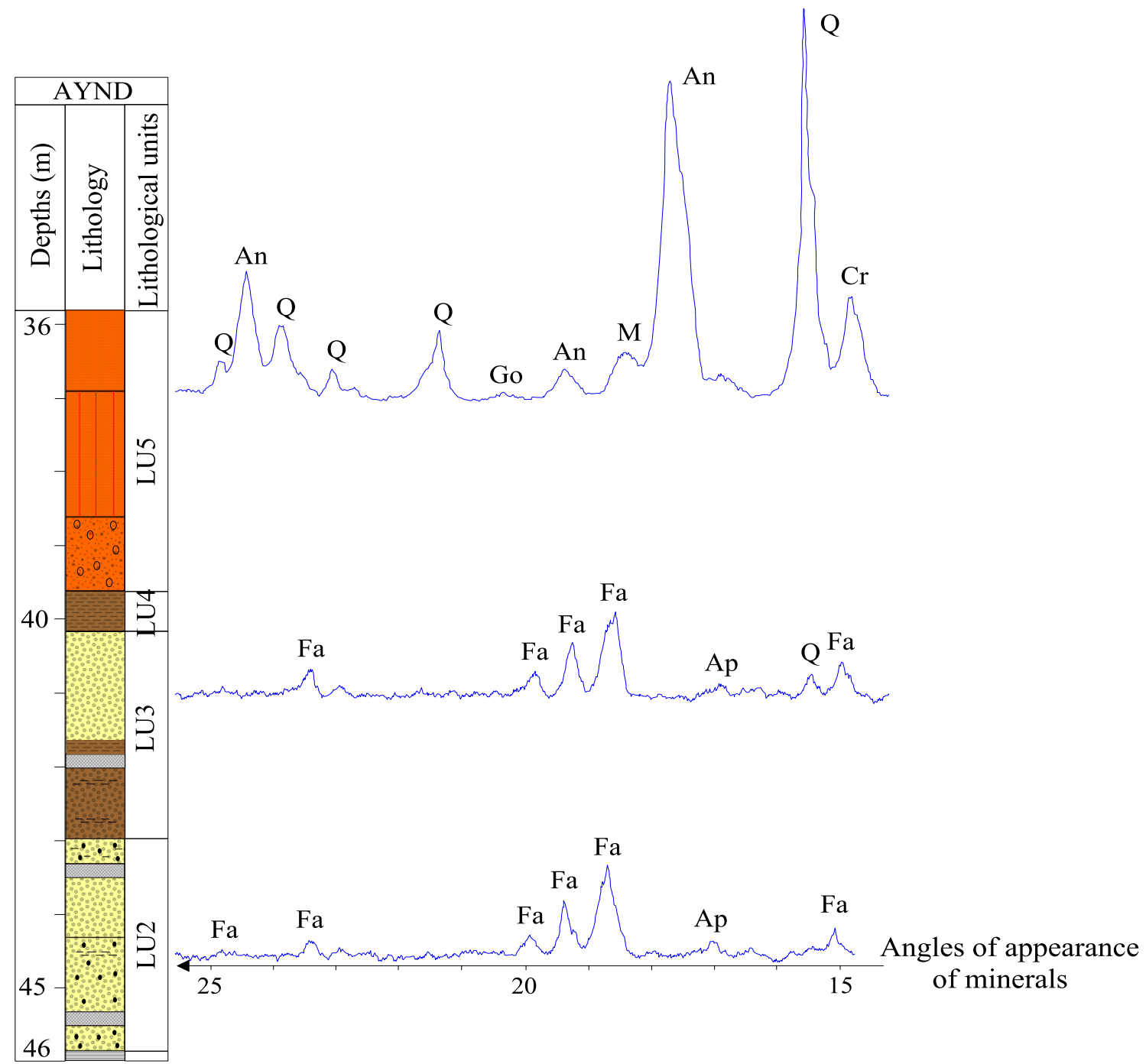

Fig. 9 Lithology of the AYND borehole and the diffractograms of the analysed phosphate samples. 


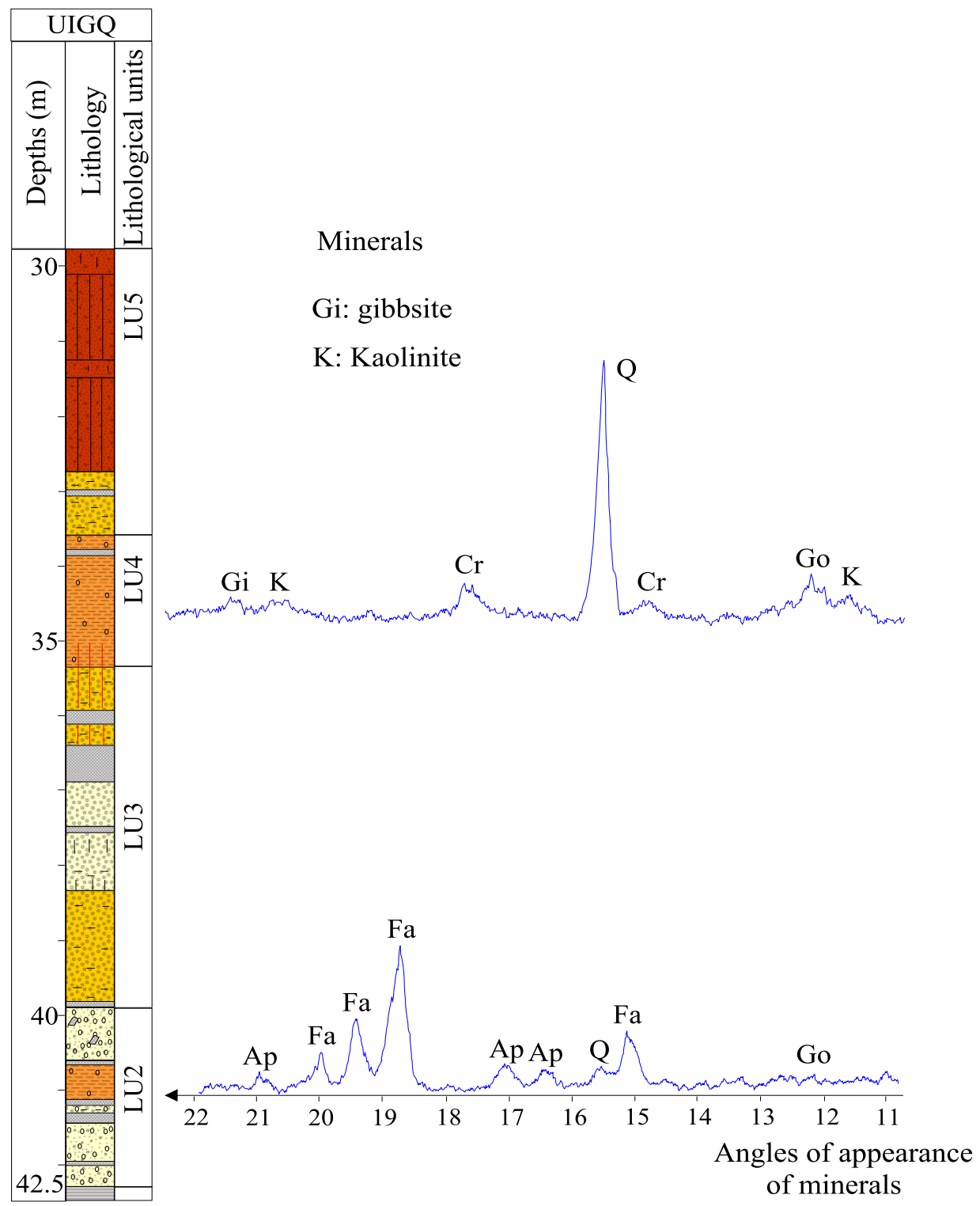

Fig. 10 Lithology of the UIGQ borehole and the diffractograms of the analysed phosphate samples.

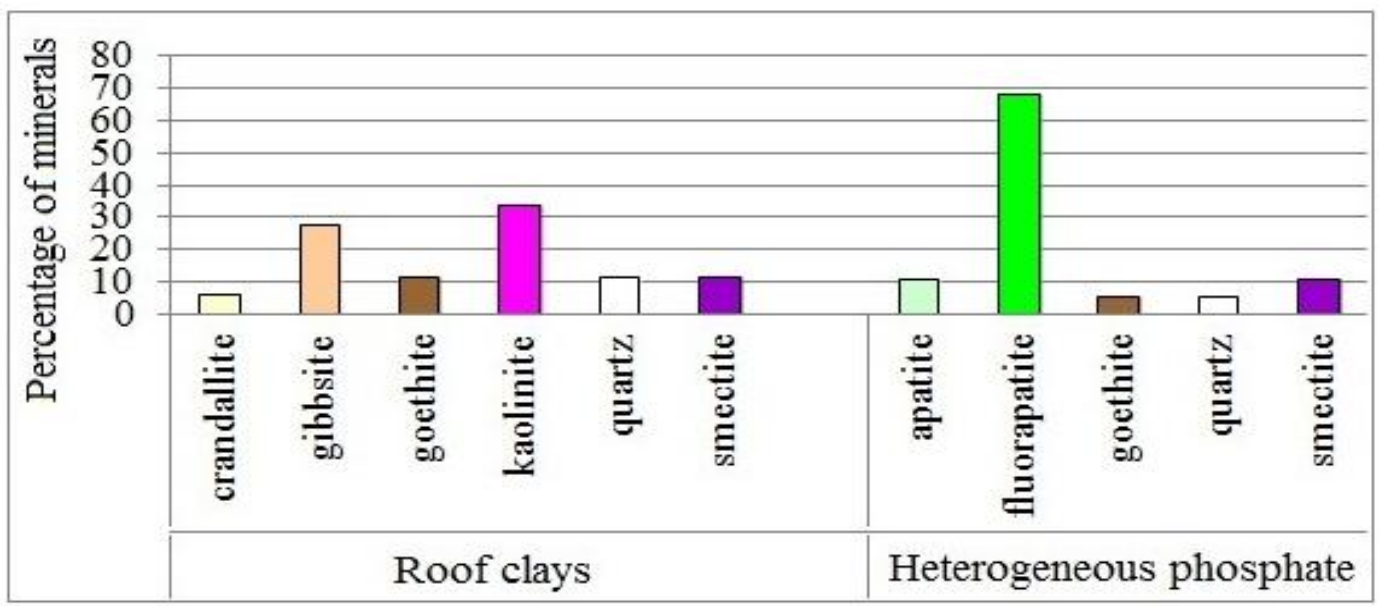

Fig. 11 Lithological units of the UIGQ borehole and their mineralogical association. 
fluorapatite, characteristic minerals of calcium phosphate. The second group is represented by goethite, quartz, kaolinite and smectite, which indicate the altered phase. The strong correlation between smectite and kaolinite indicates genetic relationships [21]. The lack of correlation between apatite and clay minerals (kaolinite and smectite) reflects the absence of a genetic relationship between these minerals.

Finally, in east central sector, the correlations reveal two mineralogical associations:

- apatite and fluorapatite;

- goethite, quartz, kaolinite and smectite.

In the eastern sector of Tobène, the correlation coefficients (Table 2) have also led to the identification of groups of minerals.

The low positive coefficient between fluorapatite and goethite indicates very weak correlation, probably due to a more important ferruginisation of the ore in this eastern sector of the panel. In addition, the positive correlation between goethite and calcite is probably the fact that ferruginous units are as well carbonated, as highlighted in the EIQQ borehole (Fig. 6). The coefficient noted between fluorapatite and smectite indicates that they do not have any genetic relationship.

In the eastern sector of Tobène, we can consider the following associations:

- fluorapatite and goethite;

- quartz, calcite, analcime, and smectite.

Ultimately, the study of the correlation coefficients revealed two groups of mineralogical associations. The apatite-fluorapatite group characterises calcium phosphate, while silico-ferralitic unit and roof clays are characterised by kaolinite, smectite, analcime, millisite, crandallite, wavellite, and goethite. However, the calcium phosphate is more altered in Eastern Tobène, as shown the correlation coefficient between fluorapatite and goethite.

These results indicate that the distribution of minerals along the phosphate series is strongly linked to lithofacies in which the alteration is growing upward.

\subsection{Study of the Spatial Distribution of the Minerals}

To better understand the mechanism of phosphate alteration, it is necessary to have an overall view of the spatial distribution of different boreholes (Fig. 12) in each of which we studied various minerals according to their abundance.

\subsubsection{Phosphated Minerals}

The distribution of minerals indicates that the main phosphated mineral is fluorapatite, which is often associated with apatite in small quantities. Fluorapatite

Table 1 Correlation coefficients of the minerals for some boreholes in the east central sector.

\begin{tabular}{lllllll}
\hline Minerals & Apatite & Fluorapatite & Goethite & Quartz & Kaolinite & Smectite \\
\hline Apatite & 1.000 & 0.678 & -0.791 & -0.867 & -0.090 & -0.160 \\
Fluorapatite & & 1.000 & -0.954 & -0.233 & -0.792 & -0.833 \\
Goethite & & & 1.000 & 0.383 & 0.648 & 0.698 \\
Quartz & & & 1.000 & -0.409 & 0.344 \\
Kaolinite & & & & & 1.000 & 0.988 \\
Smectite & & & & & & 1.000 \\
\hline
\end{tabular}

Table 2 Correlation coefficients of minerals for some boreholes from the east sector.

\begin{tabular}{|c|c|c|c|c|c|c|}
\hline Minerals & Fluorapatite & Calcite & Quartz & Analcime & Goethite & Smectite \\
\hline Fluorapatite & 1.000 & -0.121 & -0.811 & -0.955 & 0.221 & -0.983 \\
\hline Calcite & & 1.000 & -0.482 & -0.180 & 0.941 & 0.304 \\
\hline Quartz & & & 1.000 & 0.949 & -0.750 & 0.688 \\
\hline Analcime & & & & 1.000 & -0.502 & 0.882 \\
\hline Goethite & & & & & 1.000 & -0.036 \\
\hline Smectite & & & & & & 1.000 \\
\hline
\end{tabular}




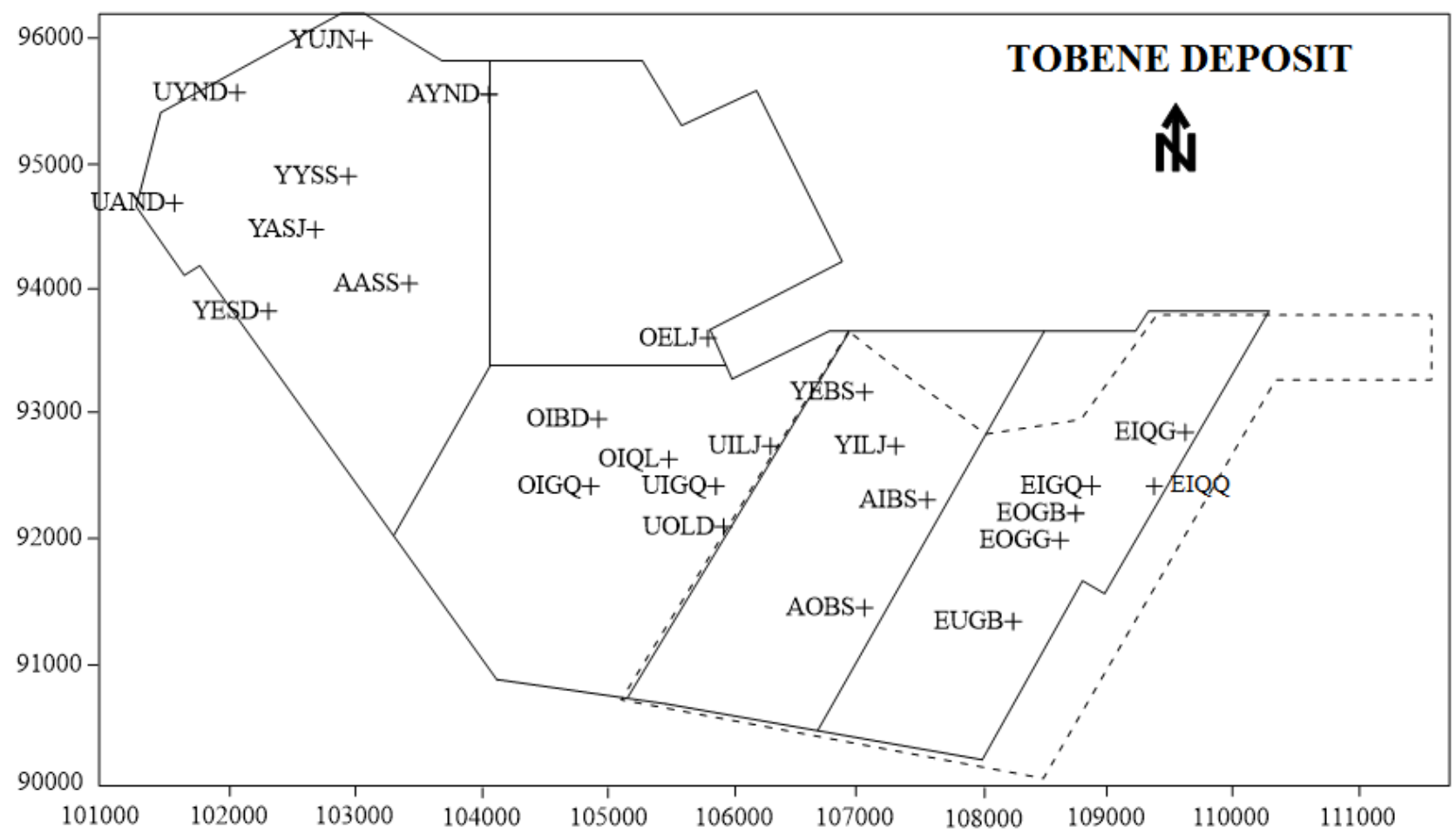

Fig. 12 Map of the spatial distribution of boreholes.

is present in almost all the phosphate samples studied. Moreover, the low proportion of apatite, compared to fluorapatite is the result of a partial transformation of apatite substitution $\mathrm{PO}_{4}^{3-}$ by $\mathrm{CO}_{3}^{2}$. The deficit of negative charge is compensated by $\mathrm{F}^{-}$. Thus, the electroneutrality is achieved by the substitution of $\mathrm{PO}_{4}^{3-}$ with $\left(\mathrm{CO}_{3}, \mathrm{~F}\right)^{3-}[22,23]$.

\subsubsection{Quartz}

Because of its resistance to alteration, quartz is by far the most frequently observed mineral. Quartz is present throughout the deposit with a varied abundance; its proportion, more important in the western sector, is observed because phosphate samples selected from it belong to the silico-ferralitic unit. In addition, the presence of chalcedony [5] and quartz grains rounded to angular [7] proves the double chemical and detrital origin of the quartz.

\subsubsection{Carbonate Minerals}

\subsubsection{Calcite}

Calcite is mainly present in the western sector but is also found in the central-south and central-east sectors. Calcite becomes less important in the east, where the quantity of dolomite is increasing. This marked decrease can be explained by the leaching of carbonates by meteoric waters. Finally, as shown by Ref. [24] in the phosphate deposits of Jordan, the discontinuous distribution of calcite through the deposit is the sign of a variability of sedimentology conditions.

\subsubsection{Dolomite}

Dolomite, often associated with calcite, has been discovered for the first time in Central-south sector (OIBD borehole). The quantity of dolomite increases towards Tobène East, where the basin deepens [25] (Fig. 13), whereas the quantity of calcite decreases. Accordingly, the occurrence of dolomite could result from the dissolution of calcite, which recrystallises with the substitution of $\mathrm{Ca}^{2+}$ by $\mathrm{Mg}^{2+}$ released by clays.

The presence of both calcite and dolomite demonstrate chemical and biochemical sedimentation [26].

\subsubsection{Alteration Minerals}

The distribution of the minerals indicates that analcime $\left[\mathrm{Na}\left(\mathrm{Si}_{2} \mathrm{AlO}_{6}\right) \mathrm{H}_{2} \mathrm{O}\right]$ has a strong affinity with quartz $\left[\mathrm{SiO}_{2}\right]$ and calcite $\left[\mathrm{CaCO}_{3}\right]$. The association 


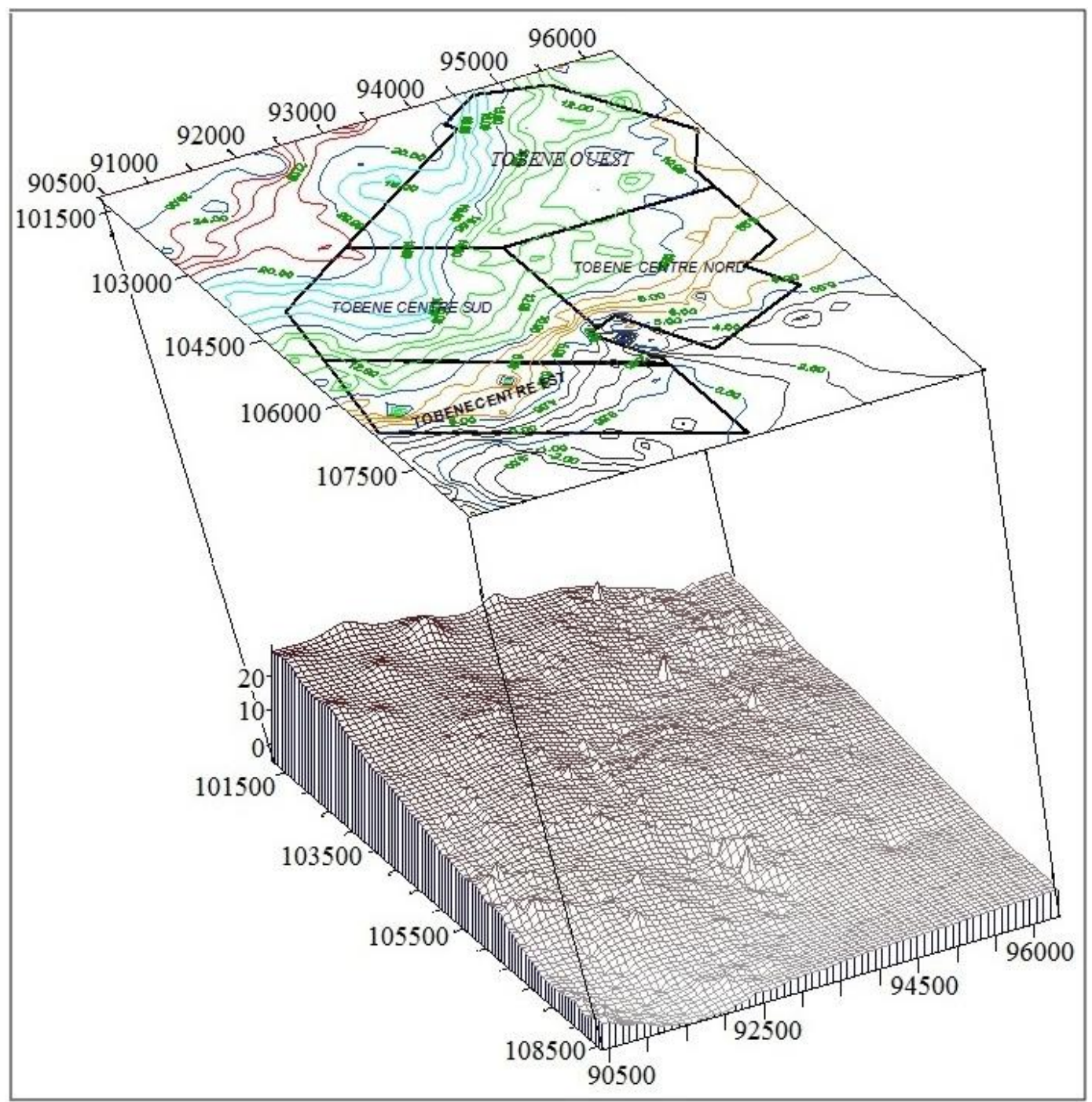

Fig. 13 Three-dimensional view of the wall structure of Tobène [25].

of analcime with quartz is interpreted as being a crystallisation of analcime from the aluminosilicate material of clays [27], whereas its relation with calcite can be explained by the possible substitution of its sodium (Na) by calcium (Ca) of the calcite. Additionally, note that analcime is, on the one hand, abundant in samples poor in fluorapatite and vice versa. On the other hand, it is more present in the summit of the phosphate series. These observations confirm the neoformation of this mineral.

Moreover, the following minerals, millisite-crandallite-wavellite, witness of a more intense differential alteration, are only noticed in the western and eastern parts of Tobène. In the West, the presence of these minerals in the silico-ferralitic unit can be explained by the lack of protective layer on it, such as clays from the roof. This lack of protection exposes this part of the ore directly to the hot and humid tropical climate, leading to the alteration of phosphate minerals (mainly fluorapatite) in the alteration minerals. However, in the deeper eastern part, the presence of these minerals in the phosphate layer is probably due to the alteration of calcium phosphate following the interaction of groundwater, intercalated clays and fluorapatite, under the influence of a hot and wet climate [5].

This alteration causes a leaching of phosphate and results in the loss of some major elements $(\mathrm{Ca}, \mathrm{P}, \ldots)$ 
that will recombine with free cations, including $\mathrm{Al}^{2+}$, $\mathrm{Fe}^{2+}$ and $\mathrm{Mg}^{2+}$, coming from disintegration of the clays to reconstitute the alteration minerals. Thus, a series of minerals appear at the expense of apatite: at first the millisite appears, then crandallite and finally wavellite [1]. This mineralogical suite reflects a relative enrichment of ore in alumina and their coexistence indicates a gradual mineralogical evolution. Depending on the intensity of the alteration, all fluorapatite may be replaced by the alteration minerals (Figs. 7 and 8).

\subsubsection{Clay Minerals}

The clayey mineralogical association is composed of palygorskite, smectite, kaolinite and illite.

The spatial distribution of the minerals reveals that palygorskite, characteristic mineral of the lithological unit of the wall, is rarely present in the samples considered for this study. The rarity of palygorskite is due to fact that the wall of phosphate is not very often sampled. The presence of palygorskite has just been noticed in the West (UAND borehole), south central (OIBD borehole) and East (EIQQ borehole) of Tobène.

Kaolinite and smectite, present throughout most of the deposit, especially in the layer overlying phosphate formation, are closely interrelated and strongly linked to fluorapatite. However, kaolinite remains the most abundant clay mineral in the analysed samples. Kaolinite comes from the alteration of attapulgite, illite and clayey beds. Additionally, kaolinite is secondary and newly formed in situ by hydrolysis of sedimentary deposits [1]. Under the conditions of a hot and humid tropical climate and acidic environment, kaolinite results from the alteration of smectite [5, 28, 29]. Thus, one could say that smectite and kaolinite have a genetic relationship.

As for smectite, it is an unstable mineral for which intense leaching leads to its destruction. The presence of smectite indicates a poor alkaline marine environment, Dunoter Segonzac [28].

Finally, illite always associated with gibbsite, kaolinite and/or smectite, is present in an irregular manner throughout the deposit, with a stronger presence in the eastern part of Tobène. According to Millot [28], illite is an inherited detrital mineral, which, under acidic conditions, changes by degradation leading to the transitional stage illite-smectite. This strong association also proves their genetic relationship.

\subsubsection{Ferrugineous Minerals}

Represented by goethite, this ferrugineous mineral is present in almost all the boreholes with varied proportions. Goethite is often combined with clay minerals, such as kaolinite and smectite. Thus, goethite may derive from $\mathrm{Fe}$ released on place during the alteration of clays. Therefore, the presence of goethite reflects a ferruginisation of the phosphate series.

\section{Conclusions}

The analysis of diffractogrammes for different units of the Tobène phosphate series and of correlation coefficients highlights a succession of mineralogical associations that is always the same and ordered from bottom to top:

Palygorskite is the characteristic mineral of attapulgite. Its presence indicates a bottom of clayey sedimentation in a calm environment. At times, this mineral is relayed by calcite, as indicated by the carbonated deposits. This mineralogical vertical variation reflects a variability of the depositional environment.

Apatite and fluorapatite characterise calcium phosphate. The original apatite is transformed into fluorapatite via substitution of $\mathrm{PO}_{4}^{3-}$ by $\left(\mathrm{CO}_{3}, \mathrm{~F}\right)^{3-}$, These minerals, in contact with the clayey beds and layer sand, can be combined with clay minerals and quartz. In this case, after leaching of the carbonate fraction and decarbonation of apatite, the alteration leads to the appearance and increase of ferruginous and aluminous phosphate [29].

The mineralogical suite (smectite, kaolinite) is 
noted especially in the layer overlying phosphate formation, thereby confirming its clayey nature.

Finally, the summit of the phosphate series is characterised by the following minerals: millisite, crandallite, wavellite, analcime, goethite, kaolinite and gibbsite. Indeed, in this summit rich in $\mathrm{Al}$, following the emersion of the depositional environment and under the action of a subtractive leaching alteration, a series of phosphatic minerals that begins with millisite appears at the expense of fluorapatite $[1,29,30]$ according to the following model:

meteoric water + fluorapatite + clays $\rightarrow$ millisite

$\rightarrow$ crandallite $\rightarrow$ wavellite $\rightarrow$ augelite.

Thus, millisite comes from both the alteration of fluorapatite and sedimentary clays under the action of water of gravity and the fluctuations of the phreatic water table. Thereafter, millisite leads to crandallite, which, in its turn, leads to wavellite. Therefore, the Fe released on site during the alteration of attapulgite, illite, among others, is trapped in goethite [31].

The succession of mineralogical associations reflects the vertical evolution of the various lithofacies from the phosphate series, of which the alteration is growing upward. This succession is the result of a complex polyphase alteration, of which each stage is characterised by a mineralogical paragenesis specific to a geochemical environment [1].

As for the lateral evolution, the mineralogical composition reflects an alteration that increases from West to East as the basin deepens.

In the end, the vertical and lateral evolution of mineralogical associations observed at Tobène is the result of a series of mineralogical and structural transformations that have led to a vertical and lateral lithofacies sequence.

\section{References}

[1] Flicoteaux, R. 1980. "Genèse des Phosphates Alumineux du Sénégal Occidental. Etapes et Guides de l'Altération." Thèse Sci., Univ. Aix-Marseille III.

[2] Monciardini, C. 1966. "La Sédimentation Eocène du Sénégal.” Mémoire B.R.G.M., 43.

[3] Samb, M. 1998. "Aspects Minéralogiques et Chimiques des Phosphates du Gisement de Tobène (Sénégal). Transformations de l'Apatite par la Diagenèse et l'Altération Pédologique." Bull. de l'IFAN Ch. A. Diop, Dakar 49 A (2): 55-77.

[4] Ly, A., Fall, M., Diouf, M. B., and Samb, E. M. 2003. Gisement de Phosphates de Tobène (Secteur Occidental) -Biostratigraphie, Sédimentologie, Evolution Paléoenvironnementale. Rapport final.

[5] Samb, M. 2008. "Géologie, Minéralogie, Pétrographie et Géochimie Minérale des Phosphates Sédimentaires du Gisement de Tobène (Sénégal). Application à une Exploitation Industrielle." Thèse de Doctorat d'Etat, U.C.A.D., I.S.T., Sénégal.

[6] Diagne, M. 2011. "Lithostratigraphie, Biostratigraphie, Minéralogie et Géochimie des Phosphates Eocènes de Tobène." Thèse de Doctorat de $3^{\text {ème }}$ Cycle, Univ. Ch. A. Diop, Dakar.

[7] Dione, N. P. 2011. "Sédimentologie et Minéralogie des Phosphates Eocènes de Tobène." Thèse de Doctorat de $3^{\text {ème }}$ Cycle, Univ. Ch. A. Diop, Dakar.

[8] Mban, A. M. 2000. "Faciès Phosphatés du Site de Tobène Centre-Est $\square$ : Lithosratigraphie, Granulométrie et Particularités Géochimiques Liées au Contexte Calcaire.” Mémoire de D.E.A., Univ. Ch. A. Diop, Dakar.

[9] Roger, J., Noël, B. J., Barusseau, J. P., Serrano, O., Nehlig, P., and Duvail, C. 2009. "Notice Explicative de la Carte Géologique du Sénégal à 1/500,000, feuilles nord-ouest, nord-est et sud-ouest." Ministère des Mines, de l'Industrie et des PME, Direction des Mines et de la Géologie, Dakar, 61.

[10] Slansky, M., Lallemand, A., and Millot, G. 1964. "La Sédimentation et l'Altération Latéritique des Sédiments Phosphatés du Gisement de Taïba." Bull. Serv. Carte Géol. Als. Lorr. 17: 311-24.

[11] Brancart, R., and Flicoteaux, R. 1971. "Age des Formations Phosphatées de Lam-Lam et de Taïba (Sénégal Occidental). Données Micropaléontologiques, Conséquences Stratigraphiques et Paléontologiques." Bull. Soc. Géol. Fr. (7) 13 (3-4): 399-408.

[12] Boujo, A. 1972. Etudes Géologiques Actualisées et Prévisions de Réserves. Rapport C.S.P.T.

[13] Y. 1995. "Etude Géologique et Géostatistique du Gîte de Phosphate de Taïba (Sénégal)." Thèse Doct. Univ. Lausanne.

[14] Diop, A. M. 2002. "La Série Phosphatée de la Partie Occidentale du Gisement de Tobène $\square$ : Lithostratigraphie, Biostratigraphie et Evolution Paléoenvironnementale." Mémoire de D.E.A., Univ. Ch. A. Diop, Dakar.

[15] Diagne, M. 2003. "Faciès Phosphates du Site de Tobène $\square$ : Essai de Caractérisation Géochimique.” Mémoire de D.E.A., Univ. Ch. A. Diop, Dakar.

[16] Dione, N. P. 2003. "Essai de Synthèse Lithologique du 
Gisement de Phosphate de Tobène." Mémoire de D.E.A., Univ. Ch. A. Diop, Dakar.

[17] Bolli, H. B., Beckmann, J. P. and Saunders, J. B. 1994. Benthic Foraminiferal Biostratigraphy of the South Cambridge Region. Cambridge University Press.

[18] Bolli, H. B., Saunders, J. B. and Perch-Nielsen, K. 1985. Plankton Stratigraphy. Cambridge University Press.

[19] Brancart, R. 1977. "Etude Micropaléontologique et Stratigraphique du Paléogène sur le Flanc Occidental du Horst de Diass et dans la Région de Taïba (Sénégal)." Thèse $3^{\text {éme }}$ Cycle, Aix-Marseille I.

[20] Berggren, W. A., and Pearson, P. N. 2005. “A Revised Tropical to Subtropical Paleogene Planctonic Foraminiferal Zonation.” J. Foraminifer. Res. 35 (4): 279-98.

[21] Baioumy, H. M. 2005. "Preliminary Data on Cadmium and Arsenic Geochemistry for Some Phosphorites in Egypt.” J. Afr. Earth Sci. 41 (3): 266-74.

[22] Abed, A. M., and Fakhouri, K. 1996. "On the Chemical Variability of Phosphatic Particles from Jordanian Phosphorite Deposits." Chem. Geol. 131 (1-4): 1-13.

[23] Soudry, D., and Nathan, Y. 2000. "Microbial Infestation: a Pathway of Fluorine Enrichment in Bone Apatite Fragments (Negev Phosphorites, Israel)." Sediment. Geol. 132 (3-4): 171-6.

[24] Abed, A. M., and Abdalla, R. S. 1998. "On the State of Weathering of the Upper Cretaceous Red Phosphorites of Eshidiya, Southern Jordan.” J. Afr. Earth Sci. 27 (1):
39-54.

[25] Sidibé, K. 2007. “Contribution à l'Etude Lithologique et Géochimique des Faciès Phosphatés de Tobène Centre." Mémoire de D.E.A., Univ. Ch. A. Diop, Dakar.

[26] Ly, A., and Anglada, R. 1991. "Le Bassin Sénégalo-Mauritanien dans l'Evolution des Marges Périatlantiques au Tertiaire." Cahiers de Micropaléontologie 6 (2): 23-57.

[27] English, P. M. 2001. "Formation of Analcime and Moganite at Lake Lewis, Central Australia: Significance of Groundwater Evolution in Diagenesis." Sediment. Geol. 143 (3-4): 219-44.

[28] Awongo, M. L. 1985. "Stratigraphie, Sédimentologie et Géochimie des Terres Noires du Jurassique Moyen et Supérieur de la Provence, Sud-Est de la France." Thèse de Doctorat de $3^{\text {ème }}$ Cycle Géologie, Univ. St Jérôme, Marseille.

[29] Gnandi, K., and Tobschall, H. J. 2003. "Distribution Patterns of Rare-Earth Elements and Uranium in Tertiary Sedimentary Phosphorites of Hahotoé-Kpogamé, Togo." J. Afr. Earth Sci. 37 (1-2): 1-10.

[30] Lucas, J., Flicoteaux, R., Nahon, Y., Prévôt, L., and Shahar, Y. 1980. "Different Aspects of Phosphorite Weathering." SEPM Special Publication (29): 41-51.

[31] Johnson, A. K., Rat, P., and Lang, J. 2000. "Le bassin Sédimentaire à Phosphates du Togo (Maastrichtien-Eocène): Stratigraphie, Environnements et Evolution.” J. Afr. Earth Sci. 30 (1): 183-200. 